\title{
IDENTITAS KETURUNAN PEREMPUAN DALAM KEJADIAN 3:15 DALAM STUDI SOTERIOLOGI
}

\author{
Pangeran Manurung \\ Sekolah Tinggi Teologi Injili Indonesia Surabaya \\ E-mail: pangeranmanurung@sttii-surabaya.ac.id
}

\begin{abstract}
One of the problems arising from the polemic of the events of the fall of man in the Garden of Eden recorded by the author of the Book of Genesis is the bias of the policy of salvation taught by the writers of the New Testament. Salvation in the New Testament is considered not to have originated in the Old Testament mind. Apart from the element of salvation in the Old Testament which is only supposed to contain "political" salvation, the clarity of the interpretation of the female offspring and its fulfillment in Jesus Christ is also questioned. Jesus Christ is considered unqualified as a descendant of the woman offended in Genesis 3 so that the eternal salvation offered by Jesus Christ in the event of the crucifixion is considered an offer of a "concept of salvation" that is not in line with the promise of salvation in Genesis 3. While other commentators state the opposite. This study will discuss it using a biblical library research approach. This means that the researcher will prove who the offspring of the woman referred to in incident 3 is based on the evidence from the Old and New Testaments. The results of this study prove that the female offspring referred to in event 3 is Jesus Christ. The phrase "bruising in the heel" in the pericope is a symbolic statement of the crucifixion event of Jesus Christ which is interpreted by New Testament readers as the salvation promised in Genesis 3:15.
\end{abstract}

Keywords: Genesis3:15, Descendants of women salvation, Jesus Christ, Redemption, New Testament.

Abstrak

Salah satu permasalahan yang ditimbulkan dari polemik peristiwa kejatuhan manusia di Taman Eden yang dicatat oleh punulis Kitab Kejadian adalah biasnya dasar keselamatan yang diajarkan oleh penulis Perjanjian Baru. Keselamatan dalam Perjanjian Baru dianggap tidak bersumber dari pikiran Perjanjian Lama. Selain karena unsur keselamatan dalam Perjanjian Lama yang hanya diduga mengandung keselamatan secara "politis", kejelasan penafsiran terhadap keturunan perempuan dan penggenapannya dalam diri Yesus Kristus juga dipertanyakan. Yesus Kristus dianggap tidak memenuhi syarat sebagai keturunan perempuan yang disinggung dalam Kejadian 3 sehingga keselamatan kekal yang ditawarkan oleh Yesus Kristus dalam peristiwa penyaliban dianggap sebagai sebuah tawaran "konsep keselamatan" yang tidak sehaluan dengan janji keselamatan dalam Kejadian 3. Sementara penafsir yang lain menyatakan kebalikannya. Penelitian ini akan membahasnya dengan menggunakan pendekatan penelitian kepustakaan yang bersifat biblika. Artinya peneliti akan membuktikan siapa keturunan perempuan yang dimaksud dalam kejadian 3 berdasarkan bukti dari Perjanjian Lama dan Perjanjian Baru. Hasil dari penelitian ini membuktikan bahwa keturunan perempuan yang dimaksud dalam kejadian 3 
adalah Yesus Kristus. Frase "meremukkan tumit" dalam perikop merupakan pernyataan simbolis atas peristiwa penyaliban Yesus Kristus yang dimaknai oleh para pembaca Perjanjian Baru sebagai keselamatan yang dijanjikan dalam Kejadian 3:15.

Kata Kunci: Kejadian 3:15, Keturunan Perempuan, Dasar Keselamatan, Yesus Kristus, Penebusan, Perjanjian Baru.

\section{PENDAHULUAN}

Kajian tentang dasar keselamatan Perjanjian Baru yang dihubungkan dengan janji Allah dalam Kejadian 3 telah jamak dilakukan. Terdapat masalah tentang identitas perempuan yang dibicarakan, apakah Hawa atau Maria. ${ }^{1}$ Sebagian secara jelas menafsirkan perempuan sebagai Maria, tetapi yang lain tidak secara spesifik menjelaskan siapa perempuan yang dimaksud. $^{2}$ Wiersbe sendiri hanya mendekati perikop ini untuk keperluan penebusan di dalam Kristus tanpa secara

\footnotetext{
${ }^{1}$ https://www.katolisitas.org/maria-adalahperempuan-yang-disebutkan-di-dalam-kitabkejadian/ . Katolik meyakini bahwa perempuan dalam Kejadian 3 adalah Maria. Seperti yang ditulis dalam blog, "Bunda Maria sudah dinubuatkan, 'benih dari perempuan ini akan menjadi penyelamat dunia, dan bahwa iblis akan bertekuk lutut di kakinya" (Kej 3:15) Atas dasar apa sdr. Maria menyimpulkan bahwa perempuan tsb adalah Maria? Kesamaan apa yang ada pada Maria dgn "perempuan" yg disebut dalam ayat tsb? Apakah dia perempuan... banyak perempuan di Israel... apakah dari benih perempuan? Kita juga dari benih perempuan.. Dan di akhir dunia, seperti disebutkan di kitab Wahyu, Bunda Maria dimahkotai di surga (Why 12: 1) yang melahirkan Sang Penyelamat Wahyu 12:1 : .... Seorang perempuan berselubungkan...... Atas dasar apa sdr. Maria menyimpulkan bahwa perempuan tsb. adalah Maria? Disebutkan juga yang dilahirkan bukanlah Juru Selamat melainkan Seorang "Anak laki-laki, yang
}

tegas mengulas sosok perempuan dan keturunannya. ${ }^{3}$ Matthew Henry meyakini bahwa perempuan yang dimaksud dalam teks ini adalah Maria, mengikuti pendapat katolik dan tradisi Bapa Gereja. ${ }^{4}$ Masalah lain adalah tentang identitas yang meremukkan ular atau setan. Penggunaan jenis maskulin atau feminin dalam kata "nya" atau "dia" dalam perikop dianggap sebagai kunci untuk menjelaskan identitas yang akan memenuhi kualifikasi penyelamatan. ${ }^{5}$ Mengenai identitas pihak yang meremukkan Iblis, Keil berpendapat

akan menggembalakan semua bangsa dengan gada besi" karena kelahiran Juru Selamat sudah digenapi. Perempuan itu adalah Mempelai Wanita dari Mempelai Pria Sorgawi. Apakah Maria yang menjadi Mempelai Wanita? Ibu \& Anak yang pernah dilahirkan akan menikah?! Very funny"

2 Bible Knowledge Commentary; Old Testament (Cook Communications Ministries; Bible Knowledge Commentary, 2000)

${ }^{3}$ Wiersbe, Wiersbe's Expository Old Testament (Cook Communications Ministries, 2000)

${ }^{4}$ Matthew Henry, Commentary on the Whole Bible (PC Study Bible Formatted Electronic Database, 2006)

${ }^{5}$ Rita Wahyu menjelaskan bahwa jenis gender yang digunakan dalam Kejadian 3 adalah 
bahwa oknum tersebut adalah Yesus. ${ }^{6}$

Penelitian ini akan menelisik identitas keturunan perempuan dan melihat penggenapannya bermuara kepada sosok yang mana. Dengan kata lain, peristiwa penghukuman Allah yang diutarakan oleh penulis Kejadian 3 akan dihubungkan dengan doktrin keselamatan, secara khusus kepada konsep penebusan dalam Perjanjian Baru.

\section{METODE PENELITIAN}

Metode yang digunakan dalam pemecahan permasalahan penelitian ini menggunakan pendekatan studi pustaka, secara khusus menggunakan sudut pandang biblika. Peneliti akan menelisik identitas keturunan perempuan yang dimaksud dalam Kejadian 3:15 berdasarkan studi gramatikal-leksikal dan melihat penggenapannya dalam kitab-kitab sesudahnya. Setelah itu, peneliti akan mengkaji "orang” yang dimaksud berdasarkan pendekatan teologis, khususnya dari kacamata doktrin keselamatan.

\section{HASIL DAN PEMBAHASAN}

Pembahasan dalam tulisan ini mencakup beberapa aspek, sebagai berikut;

\section{KONTEKS KITAB KEJADIAN 3:15}

Kitab Kejadian 3:15 berbunyi demikian: "Aku akan mengadakan permusuhan antara engkau dan perempuan ini antara keturunanmu dan keturunannya; keturunannya akan meremukkan kepalamu dan engkau akan meremukkan tumitnya." Bila ayat ini dianalisa berdasarkan konteksnya, dapat terlihat sebagai berikut:

\section{Konteks Sebelumnya}

Dalam Ayat 1-5: Menceritakan peristiwa bagaimana cerdiknya ular menggoda Hawa. Di ayat 1, si ular menyampaikan Firman Tuhan: "Tentulah Allah berfirman: semua pohon dalam taman ini jangan kamu makan buahnya bukan?" Hal ini sesuai dengan perintah Tuhan kepada manusia (Band. Kej. 2:1617). Sahut perempuan pada ayat $2-3$, membuktikan kepolosannya yang belum tercemar oleh dosa. Ularpun mengetahui akan hal ini, namun tidak kehilangan akal untuk terus menggoda. Ia mulai

6 Keil and Delitzsch, Commentary on the Old Testament: New Updated Edition, Electronic Database (Hendrickson Publishers, 1996) "keturunannya" dalam perikop tersebut merujuk kepada Mesias, Yesus Kristus. Selengkapnya lihat blognya di http://www.sarapanpagi.org/kejadian-315-siapa-yang-meremukkan-kepala-ularvt2442.html 
membelokkan Firman Tuhan "sekali-kali kamu tidak akan mati, tetapi Allah akan mengetahui, bahwa pada waktu kamu makan matamu akan terbuka, dan kamu akan menjadi seperti Allah, tahu tentang yang baik yang yang jahat" (Kej. 3:4-5). Pembelokkan Firman Tuhan yang disampaikan ular kepada Hawa bahwa "ia akan menjadi sama seperti Allah" ketika memakan buah pohon tersebut, menggoda hatinya. Perempuan mulai melihat buah pohon itu baik untuk dimakan dan sedap kelihatannya dan pada akhirnya ia memakannya dan memberikan kepada suaminya Adam (ay. 6). Godaan perempuan membuat Adam tidak berdaya. Ia langsung memakan buah pohon larangan Allah, tanpa berkata-kata sedikitpun untuk menegur Hawa istrinya.

Lebih lanjut pada ayat 7-13: Menunjukkan usaha-usaha manusia setelah jatuh dalam dosa. Sebelum kejatuhan manusia ke dalam dosa, semuanya berada dalam keadaan harmonis dan intim, tetapi sekarang timbul rasa malu atas ketelanjangan mereka (ay 7). ${ }^{7}$ Ketika manusia sudah melakukan penggaran terhadap perintah Allah, "mereka baru tahu bahwa mereka adalah telanjang; lalu mereka menyamat daun pohon ara dan

\footnotetext{
${ }^{7}$ W.S. Lasor, D.A. Hubbar, F.W. Bush, Pengantar Perjanjian Lama 1 Taurat dan Sejarah (Jakarta: BPK Gunung Mulia, 2011), 127-128
}

membuat cawat" (Ay. 7). Ini merupakan usaha pertama yang dilakukan oleh manusia untuk menyelamatkan diri akibat pelanggaran mereka. Kemudian, usaha kedua yang dilakukan oleh manusia adalah bersembunyi terhadap Tuhan. Ketika manusia sudah jatuh, mereka tidak mencari Tuhan tetapi tetapi justru bersembunyi dihadapan-Nya. Allah mengetahui hal ini, dan membuat-Nya berinisiatif sendiri untuk mencari manusia (ay. 8). Allah memanggil manusia: "Dimanakah engkau?” (ay. 9). Lalu manusia memberi jawaban jujur kepada Allah bahwa ia bersembunyi karena takut ketika mengetahui bahwa ia telanjang (ay. 10). Meskipun Allah mengetahui akan hal ini, namun Ia terus mengajak manusia untuk bercakap-cakap dengan-Nya meskipun hati Tuhan sedang mengalami berbagai rasa. Pada ayat 10-13, menunjukkan betapa kacaunya keadaan setelah kejatuhan. Manusia terus berusaha membela diri di hadapan Tuhan. Adam menyalahkan Hawa (ay. 12), Hawa menyalahkan ular (13). Ini merupakan Usaha ketiga kalinya yang dilakukan oleh manusia untuk membela diri di hadapan Tuhan. Sementara di ayat 14, berkaitan dengan hukuman yang diberikan oleh Tuhan atas ular yang menggoda manusia. 
Allah tidak membiarkannya untuk berkatakata, tidak seperti Adam dan Hawa yang diajak berdialog oleh Allah (ay. 9-13).

Tinjauan yang lebih teliti terhadap konteks sebelum ayat ke 15 menyungguhkan bahwa janji Allah dalam Kejadian 3:15 sangat berkaitan dengan keselamatan. Pertama, semua usaha-usaha yang dilakukan manusia untuk membela diri di hadapan Allah setelah kejatuhan, ternyata tidak bisa menyelamatkan dan pada akhirnya Tuhan menghukumnya. Kedua, karena usaha-usaha manusia tidak bisa membawa keselamatan, Tuhan sendiri yang memiliki inisiatif untuk mencari, menemukan manusia dan memprakarsai keselamatan. Tindakan Allah untuk mencari, memanggil, bercakap-cakap membuktikan kesungguhan-Nya untuk mengasihi manusia.

\section{Konteks Sesudahnya:}

Berlanjut pada analisa konteks setelah Kej. 3:15. Dalam ayat 16-19, Tuhan menyatakan hukuman bagi manusia. Ia menghukum perempuan: "Susah payahmu waktu mengandung akan kubuat sangat banyak; dengan kesakitan engkau akan melahirkan anakmu; namun engkau akan berahi kepada suamimu dan ia akan

\footnotetext{
8 John H. Sailhamer, The Expositor's Bible Comementary with the New International Version of
}

berkuasa atasmu (17)." Begitu pula dengan Adam, Allah menghukumnya:

"Karena engkau mendengarkan perkataan isterimu dan memakan dari buah pohon, yang telah Kuperintahkan kepadamu: Jangan makan dari padanya, maka terkutuklah tanah karena engkau; dengan bersusah payah engkau akan mencari rezekimu dari tanah seumur hidupmu: semak duri dan rumput duri yang akan dihasilkannya bagimu, dan tumbuhtumbuhan di padang $\stackrel{l}{a}$ akan menjadi makananmu; dengan berpeluh engkau akan mencari makananmu, sampai engkau kembali lagi menjadi tanah, karena dari situlah engkau diambil; sebab engkau debu dan engkau akan kembali menjadi debu."

Kemudian pada ayat 20, Adam memberi nama Hawa kepada Istrinya yang artinya ibu semua yang hidup. Ini merupakan kali kedua Adam memberikan nama kepada istrinya. Pemberian nama yang pertama adalah terdapat dalam Kejadian 2:23 dinamai "Perempuan”. Nama yang pertama ini menunjuk pada asal usulnya yakni diambil dari laki-laki; sedangkan yang kedua dalam Kejadian 3:20 menunjuk pada tujuannya yaitu ibu semua yang hidup. ${ }^{8}$ Kata Hawa dalam bahasa

the Holly Bible (Grand Rapids, Michigan: Zondervan Publishing House, 1991), 2:57 
Jurnal Teologi \& Pelayanan ( Kerusso )

E-ISSN: 2714-9587

P-ISSN: 2407-554X

Ibrani adalah (Hawwāh) artinya adalah hidup.9 Secara fonetis kata Ibrani Ḥawwāh berhubungan dengan hāayâ yang berarti "hidup", sehingga melalui permaninan fonetis ini, Adam menjelaskan mengapa perempuan itu diberi nama Hawa.10 Sementara dalam Septuaginta (LXX) menerjemahkan kata (Hawwāh) dengan kata Yunani $\zeta \omega \eta$ - zôê yang secara literal berarti "hidup". ${ }^{11}$ Berdasarkan hal ini dapat berarti bahwa kata חִ̣ị (Hawwāh) ini berhubungan dengan kehidupan. ${ }^{12}$ Dengan demikian, pemberian nama Hawa "Ibu semua yang hidup" oleh Adam kepada istrinya merupakan bukti dari imannya. Ia percaya bahwa keturunan perempuan akan memberikan "kehidupan" bagi manusia seperti janji Allah di ayat 15. Beralih pada ayat 21-24. Penelusuran dalam konteks ini menunjukkan kasih Allah yang baik bagi manusia. Atas inisiatif-Nya, Ia membuatkan pakaian dari kulit binatang untuk Adam dan Hawa dan mengenakannya pada mereka (ay. 21). Kemudian, ayat 22-24 menceritakan tindakan Allah yang Adil dan bijaksana mengusir manusia dalam taman

9 Kenneth A. Mathews, The New American Comentary: An Exegetical and Theological Expoxition of Holly Seripture, Peny., E. Ray Clendenen (tk: Broadman \& Holman Publisher, 1966), 254

10 Kenneth A. Mathews, The New American Comentary: An Exegetical and Theological Expoxition of Holly Seripture, Peny., E. Ray
Eden.

Berdasarkan konsep sesudah kejadian 3:15, memberikan point bahwa: Pertama, akibat dosa manusia layak untuk mendapat hukuman. Hal ini terlihat melalui tindakan Allah untuk menghukum perempuan dan Adam. Ia juga mengusir mereka dari taman Eden, dimana para teolog menafsirkan pengusiran ini agar manusia tidak hidup selama-lamanya di dalam dosa (Band. ay. 22). Kedua, Tindakan Allah untuk membuat dan mengenakan pakaian kepada manusia yang telanjang merupakan bukti bahwa kasih Allah pada manusia tidak bisa digagalkan oleh situasi apapun.

Berdasarkan analisa kontekstual di atas, memberikan esay bahwa sehebat apapun usaha yang ditempuh oleh manusia untuk menutupi dosa, Tuhan tetap mengetahui dan menghukumnya. Ketika manusia jatuh dalam dosa, mereka bersembunyi, menyamat daun pohon ara serta membuat cawat dan berusaha membela diri dengan mempersalahkan satu sama lain, tetapi Allah tetap menghukumnya. Meskipun demikian,

Clendenen (tk: Broadman \& Holman Publisher, 1966), 254

${ }^{11}$ W. E. Vince, Merrill F. Unger dan William White, Vine's Complete Expository Dictionary of Old and New Testament Words (Nashville, Atlanta: Thomas Nelson Publisher, 1996), 254

${ }^{12}$ Keyle M. Yates, Tafsiran Alkitab Wyclife:

Kejadian-Ester (Malang: Gandum Mas, 2004), 1:41 
kuasa dosa tidak bisa membatalkan kasih

Allah yang begitu besar pada manusia.

Tuhan memprakarsai keselamatan dengan janji "benih perempuan akan meremukkan kepala ular". Allah sendiri yang berinisiatif untuk memberikan keselamatan sebagaimana dijanjikan dalam kejadian 3:15 sesaat setelah manusia jatuh di dalam dosa janji itu disampaikan secara sepihak unilateral. ${ }^{13}$ Setelah kabar baik ini disampaikan oleh Allah, Ia memulainya dengan membuat pakaian dari kulit binatang untuk menutupi ketelanjangan manusia akibat pelanggaran. Mengacu pada analisa konteks ini, memperlihatkan bahwa untuk menutupi aib Adam dan Hawa harus ada tumpahan darah dan kematian. Tuhan memulainya dengan mengorbankan binatang dan membuatkan pakaian bagi manusia. Untuk melihat tentang "siapa keturunan perempuan dan ular pada ayat 15 serta hubungannya dalam konsep keselamatan", akan dijelaskan pada penyelidikan lebih jauh melalui study biblika pada bagian selanjutnya.

\section{IDENTITAS PEREMPUAN DAN KETURUNANNYA}

Identitas tentang siapa perempuan dalam Kejadian 3:15 memang tidak dijelaskan secara terang benderang. Gereja katolik dan tradisi sebagian Bapa Gereja menyebutkan bahwa "perempuan" dalam perikop ini adalah Maria.

Gereja Katolik mendasarkan arti ayat tersebut pada pemahaman para Bapa Gereja. Menurut para Bapa Gereja, kata "perempuan" yang dimaksud di sini bukanlah Hawa, tetapi Hawa yang baru ('New Eve'). Para Bapa Gereja membaca ayat ini sebagai nubuatan akan kelahiran Yesus (Adam yang baru) melalui Bunda Maria (Hawa yang baru). Hal ini sudah menjadi pengajaran Gereja sejak abad ke-2 oleh Santo Yustinus Martir, Santo Irenaeus dan Tertullian, yang lalu dilanjutkan oleh Santo Agustinus (abad ke -5). Sayangnya, memang dalam terjemahan bahasa Indonesia, pada ayat ini dikatakan 'perempuan ini', seolah-olah menunjuk kepada Hawa, namun sebenarnya adalah 'the woman' (bukan this woman) sehingga artinya adalah sang perempuan, yang tidak merujuk kembali ke lakon yang baru saja dibicarakan. Ungkapan 'woman' atau 'perempuan' ini yang kemudian kerap diulangi pada ayat Perjanjian Baru, misalnya pada mukjizat di Kana (Yoh 2:4), dan di kaki salib Yesus, saat Ia menyerahkan Bunda Maria kepada Yohanes

13 Chris Marantika, Doktrin Keselamatan dan Kehidupan Rohani (Yogyakarta: Iman Press, 2002) 17 
murid kesayanganNya (Yoh 19:26) dan pada Kitab Wahyu (Why 12). Pada kesempatan tersebut, Yesus mau menunjukkan bahwa Maria adalah 'sang perempuan' yang telah dinubuatkan pada awal mula dunia sebagai 'Hawa yang baru' 'Hawa yang baru' ini berperan berdampingan dengan Kristus sebagai 'Adam yang baru'. Santo Irenaeus (abad ke2), mengatakan, "Ikatan yang disebabkan oleh ketidak-taatan Hawa telah diuraikan karena ketaatan Maria" sehingga selanjutnya dikatakan, "maut (karena dosa) didatangkan oleh Hawa, tetapi hidup (karena Yesus) oleh Maria." Oleh karena itu, Allah membuat Bunda Maria tidak tercemar sama sekali oleh dosa, supaya ia, dapat ditempatkan bersama Yesus di tempat utama dalam pertentangan yang total melawan Iblis (Kej 3:15). ${ }^{14}$

Menurut katolik, salah satu dasar untuk menafsirkan bahwa perempuan dalam Kitab Kejadian adalah Maria karena dalam Kitab Wahyu, Bunda Maria disebut sebagai "perempuan" yang melahirkan seorang Anak laki-laki, yang menggembalakan semua bangsa, yang akhirnya mengalahkan naga yang adalah Iblis (Why 12: 1-6). Lebih lanjut disebutkan bahwa kemenangan Bunda Maria atas Iblis ini dimungkinkan karena dalam diri Maria tidak pernah ada setitik dosa pun yang menjadi 'daerah kekuasaan Iblis'. Memang di sini tidak dikatakan secara eksplisit bahwa anak laki-laki ini adalah Juruselamat, tetapi sesungguhnya hal ini merupakan interpretasi yang paling umum yang dipegang oleh para Bapa Gereja dan para ahli Kitab Suci. Interpretasi lain dari 'anak laki-laki yang menggembalakan semua bangsa' adalah Gereja. Dalam kedua interpretasi ini tidak mengubah kenyataan bahwa Maria adalah sang “perempuan”itu, sebab dengan melahirkan Yesus yang sebagai Kepala Gereja, maka Maria melahirkan Gereja yang merupakan Tubuh Kristus (sebab tidak mungkin seseorang dilahirkan hanya kepalanya saja, melainkan dengan tubuhnya juga).

Lebih lanjut dijelaskan bahwa walaupun demikian, pengajaran di atas tidak bertentangan dengan pengajaran bahwa Maria, mewakili Gereja, adalah mempelai wanita dari Anak Domba (Kristus) yang disebutkan juga di Kitab Wahyu, sebab pengertian 'perjamuan kawin' Anak Domba yang disebutkan di Kitab Wahyu (Why 19:7) tidak sama dengan arti perkawinan di dunia, walaupun keagungan dan nilai persatuannya telah

\footnotetext{
${ }^{14}$ https://www.katolisitas.org/maria-adalahperempuan-yang-disebutkan-di-dalam-kitabkejadian/
} 
sedikit digambarkan melalui sakramen perkawinan, seperti yang telah diajarkan oleh Yesus di dalam Efesus 5:22-32. Yesus mengajarkan agar para suami menyerahkan diri bagi istrinya, sama seperti Ia menyerahkan diri-Nya bagi Gereja-Nya. Karena Maria merupakan Bunda Gereja, dan sekaligus juga anggota Gereja (karena ialah orang pertama yang menjadi murid Kristus dengan kesediaannya menjadi Ibu Yesus), maka Maria adalah sekaligus Bunda Kristus dan Mempelai Kristus. Sekali lagi, 'Mempelai Kristus' di sini tidak dapat disamakan artinya dengan arti mempelai dalam arti duniawi, sebab kedalaman artinya jauh melebihi pemikiran manusia. Rasul Paulus menyebut hubungan kasih antara Kristus dan GerejaNya sebagai "rahasia besar" (Ef 5:32), yang tentu akan mencapai pemenuhan sempurnanya pada akhir zaman, namun yang sekarang telah mulai dinyatakan dalam persatuan Kristus dengan Gereja-Nya melalui sakramen Ekaristi, dimana Gereja dipersatukan oleh Kristus dengan menyambut Tubuh, Darah, Jiwa dan Ke-Allahan-Nya di dalam Ekaristi. Namun jika dicermati berdasarkan konteks perikop, akan lebih masuk akal jika perempuan yang dimaksud dalam kejadian 3 adalah Hawa tetapi juga tanpa menyingkirkan Maria dalam pembahasan. Maria merupakan keturunan Hawa sebagai ibu dari kaum wanita dan pada penggenapannya dalam Perjanjian Baru, kaum Kristen meyakini bahwa Maria merupakan ibu dari Yesus.

\section{Gender Keturunan Perempuan} Walaupun Kejadian 3:15 masih tergolong "buram" dalam memperkenalkan keturunan perempuan yang akan mengalahkan Iblis, namun pelacakan tetap dilakukan melalui penyelidikan penggunaan jenis gendre dalam teks Ibraninya.

\begin{tabular}{|c|c|}
\hline $\begin{array}{c}\text { Teks Ibrani } \\
\text { (WTT) }\end{array}$ & $\begin{array}{c}\text { Teks Indonesia } \\
\text { (ITB) }\end{array}$ \\
\hline 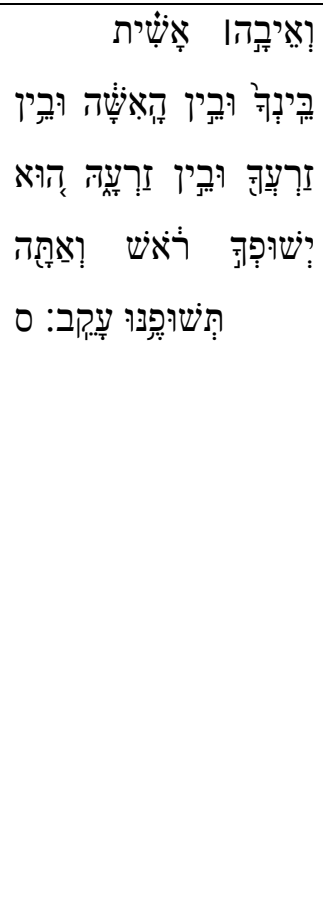 & $\begin{array}{l}\text { Aku akan } \\
\text { mengadakan } \\
\text { permusuhan antara } \\
\text { engkau dan } \\
\text { perempuan ini, } \\
\text { antara keturunanmu } \\
\text { dan keturunannya; } \\
\text { keturunannya akan } \\
\text { meremukkan } \\
\text { kepalamu, dan } \\
\text { engkau akan } \\
\text { meremukkan } \\
\text { tumitnya." }\end{array}$ \\
\hline
\end{tabular}

Istilah "keturunannya meremukkan"

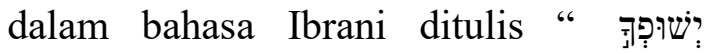
(yeshufkha) yang berarti "dia meremukkanmu" menggunakan gender maskulin. Artinya, orang ketiga yang digunakan dalam teks menggunakan gender 
Jurnal Teologi \& Pelayanan ( Kerusso )

E-ISSN: 2714-9587

P-ISSN: 2407-554X

maskulin sehingga dapat mengasumsikan bahwa keturunan perempuan itu adalah laki-laki. Menurut Rita Wahyu, memang aksara הוא - HU', he-vav-alef, bisa bermakna bermakna "he, she, it". Namun aksara (dengan nikudim) - הוּאוא pronomina orang ketiga tunggal maskulin, sehingga terjemahannya adalah "ia" sebagai laki-laki (he). ${ }^{15}$ Lebih lanjut ia menjelaskan bahwa membaca aksara Ibrani tanpa Nikudim, memang sulit untuk membedakan Kata הוא - HÛ' (he-vav-alef) yang dapat digunakan untuk gender laki-laki dan dapat digunakan untuk perempuan. Namun atas dasar kaidah dan dalam pengucapan atau membaca naskah dengan nikudim akan mudah membedakan mana yang maskulin dan mana yang feminin. Mengutip Ethridge, Rita Wahyu menjelaskan perihal pembuktian bahwa Yesus Kristus adalah keturunan perempuan melalui sumber Yudaisme. Misalnya Targum Onkelos mengenai Kejadian 3:15

\footnotetext{
${ }^{15} \mathrm{http}$ ://www.sarapanpagi.org/kejadian-3-15-siapayang-meremukkan-kepala-ular-vt2442.html

${ }^{16}$ Ethridge, J. W. The Targums of Onkelos and Jonathan Ben Ussiel on the Pentateukh. Vol. 1,2. (New York: KTAV Publishing House, Inc, 1968), 41. Targum tersebut berbunyi, "And enmity I will put between you and the woman, and between your son and her son. He shall be recalling what you did to him in the beginning; and you shall be observing him in the end". Kata ganti "dia" dalam terjemahan ini menggunakan istilah "he" yang berarti keturunan yang dimaksud adalah laki-laki
}

mengatakan, "Aku akan mengadakan permusuhan antara engkau dan perempuan ini, dan antara anakmu dan anaknya. Dia akan mengingat engkau, apa yang engkau lakukan padanya sejak semula, dan pada akhirnya engkau akan tunduk kepadanya". ${ }^{16}$ Bowler menyebutkan bahwa dalamTargum Pseudo Jonathan, identitas keturunan perempuan itu disebutkan secara jelas, yaitu Mesias. ${ }^{17}$ Pernyataan ini mirip dengan apa yang disebutkan oleh Cooper dalam kutipan Rita Wahyu:

Dalam Kejadian 3:15, kita menemukan ramalan pertama tentang Penyelamat Dunia, yang disebut 'keturunan wanita.' Dalam firman aslinya Allah meramalkan permusuhan yang tidak ada habisnya antara 'keturunan wanita' dan keturunan 'ular' yang akhimya akan' dimenangkan oleh keturunan wanita. Janji masa purba ini menunjukkan suatu perjuangan di antara Mesias Israel, sang Penyelamat dunia, di satu pihak, dan Satan,

\footnotetext{
17 John Bowker, The Targums and Rabbinic Literature (London: Cambridge University Press, 1969), 122. Targum tersebut menuliskan, "Aku akan mengadakan permusuhan antara engkau dan perempuan ini, antara keturunan anak-anakmu dan keturunan anak-anaknya, dan akan terjadi bahwa bila keturunan wanita itu melakukan perintah hukum Taurat, mereka akan menyerang (engkau) dan mereka akan menghancurkan kepalamu; tetapi bila mereka meninggalkan perintah hukum Taurat, engkau yang akan menyerang (mereka), dan engkau akan mencederai tumitnya. Tapi bagi mereka akan ada obatnya, sedang bagimu tidak ada, dan kelak tumit mereka akan mengalami kesembuhan pada masa sang raja, Mesias"
} 
Jurnal Teologi \& Pelayanan ( Kerusso )

E-ISSN: 2714-9587

P-ISSN: 2407-554X

musuh jiwa manusia, di lain pihak. Janji itu akhirnya meramalkan kemenangan mutlak di pihak Mesias. Beberapa komentator percaya bahwa gaung dari janji ini serta pengertian Hawa terdapat dalam Kejadian 4:1 - pernyataan Hawa ketika Kain, putra sulungnya dilahirkan. 'Aku telah mendapat seorang anak laki-laki dengan pertolongan Tuhan.' Hawa memahami janji purba ini dengan benar, tetapi salah menerapkan pemenuhannya pada Kain, anaknya. Rupanya Hawa percaya bahwa anak yang dijanjikan itu adalah Tuhan sendiri. Beberapa komentator Yahudi pemah menyisipkan kata 'malaikat' dalam nas ini dan mengatakan bahwa Hawa mengakui bahwa anaknya adalah 'malaikat Tuhan.' Tidak ada dasar bagi pernyataan ini. ${ }^{18}$

Dalam beberapa terjemahan dari kalangan Rabinik, identitas keturunan perempuan yang dimaksud adalah laki-laki tunggal. ${ }^{19}$ Menurut Rita, pemenuhan nubuat ini dapat dilihat dalam kitab-kitab setelah Kejadian. Misalnya dalam Yesaya 7:14, "Sebab itu Tuhan sendirilah yang akan memberikan kepadamu suatu pertanda: Sesungguhnya, seorang perempuan muda mengandung dan akan melahirkan

\footnotetext{
${ }^{18}$ David L Cooper, God and Messiah (Los Angeles: Biblical Research Society), 8-9

${ }^{19}$ Misalnya dalam terjemahan Torah, kalangan Rabinik disebutkan, "I will plant hatred between you and the woman, and between your offspring and her offspring. He will strike you in
}

seorang anak laki-laki, dan ia akan menamakan Dia Imanuel" dan digenapi dalam Kitab Perjanjian baru (Mat.1:18; 24).

\section{YESUS KRISTUS DAN \\ PROTOEVANGELIUM}

Dilema Teologis dalam Essay sebelumnya telah meragukan hubungan keselamatan dengan janji Allah dalam Frasa "Keturunan Pempuan Mengalahkan Ular". Kitab Suci memperlihatkan konsistensi Allah mewujudkan covenant karya keselamatan. Bagian ini akan mininjau secara Biblika tentang hubungan identitas perempuan dalam Kejadian 3 dan penggenapannya dalam pelayanan Yesus Kristus.

\section{Yesus dan Iblis dalam Isu Keturunan}

Frasa "Keturunan" dalam bahasa Ibrani adalah “זרע- zara” yang berarti "Benih atau Keturunan”. Biasanya dalam Alkitab, seorang anak disebut sebagai "benih / keturunan" ayahnya (laki-laki)

the head, and you will strike him in the heel". Sementara terjemahan Torah, kalangan Mesianik dituliskan, "And I will put enmity between thee and the woman, and between thy seed and her seed". 
secara eksklusif. Contohnya; Yesus disebut "keturunan Daud" di Roma 1: 3, dan seluruh bangsa Israel disebut sebagai "keturunan Yakub" di Yeremia 33:26. Karena konteks dalam perokop Kejadian Pasal 3, membahas tentang kejatuhan manusia dalam dosa, maka patut diyakini bahwa keturunan perempuan yang dimaksud adalah Yesus Kristus yang diramalkan lahir dari perawan suci.

Targum Onkelos yang bersumber dari Yahudi mencatat mengenai Kejadian 3:15, "And enmity I will put between you and the woman, and between your son and her son. He shall be recalling what you did to him in the beginning; and you shall be observing him in the end". ("Aku akan mengadakan permusuhan antara engkau dan perempuan ini, dan antara anakmu dan anaknya. Dia akan mengingat engkau, apa yang engkau lakukan padanya sejak semula, dan pada akhirnya engkau akan tunduk kepadanya.)" ${ }^{20}$ Begitu pula dengan Targum Pseudo Jonathan dalam Kejadian 3:15 menuliskan: "Aku akan mengadakan permusuhan antara engkau dan perempuan ini, antara keturunan anak-anakmu dan keturunan anak-anaknya, dan akan terjadi bahwa bila keturunan wanita itu melakukan

20 J.W. Ethridge, The Targums of Onkelos and Jonathan Ben Ussiel on the Pentateukh. Vol. 1,2. (New York: KTAV Publishing House, 1968) 41 perintah hukum Taurat, mereka akan menyerang (engkau) dan mereka akan menghancurkan kepalamu; tetapi bila mereka meninggalkan perintah hukum Taurat, engkau yang akan menyerang (mereka), dan engkau akan mencederai tumitnya. Tapi bagi mereka akan ada obatnya, sedang bagimu tidak ada, dan kelak tumit mereka akan mengalami kesembuhan pada masa sang raja, Mesias."21 Nubuat ini diyaniki oleh orang Yahudi sebagai pengharapan akan Mesianik yang akan datang.

Nubuat selanjutnya tentang kelahiran Mesias tercatat dalam Yesaya 7:14, "Sebab itu Tuhan sendirilah yang akan memberikan kepadamu suatu pertanda: Sesungguhnya, seorang perempuan muda mengandung dan akan melahirkan seorang anak laki-laki dan ia akan menamakan Dia Imanuel." Orang Kristen meyakini bahwa nubuat ini tergenapi melalui kedatangan Yesus seperti yang dikisahkan dalam Injil Matius 1:18, 24, dan 25 yang berbunyi: ay. 18: "Kelahiran Yesus Kristus adalah seperti berikut: Pada waktu Maria, ibu-Nya, bertunangan dengan Yusuf, ternyata ia mengandung dari Roh Kudus, sebelum mereka hidup sebagai suami isteri. Ay. 24:

\footnotetext{
${ }^{21}$ John Bowker, The Targums and Rabbinic Literature (London: Cambridge University Press, 1969), 122
} 
Sesudah bangun dari tidurnya, Yusuf berbuat seperti yang diperintahkan malaikat Tuhan itu kepada-Nya. Ia mengambil Maria sebagai isterinya, Ay. 25: tetapi tidak bersetubuh dengan dia sampai ia melahirkan anaknya dan Yusuf menamakan Dia Yesus. Dalam Injil Lukas 1: 27-35 juga diceritakan tentang peristiwa kelahiran Yesus

"Dalam bulan yang keenam Allah menyuruh malaikat Gabriel pergi ke sebuah kota di Galilea bernama Nazaret, kepada seorang perawan yang bertunangan dengan seorang bernama Yusuf dari keluarga Daud; nama perawan itu Maria. Ketika malaikat itu masuk ke rumah Maria, ia berkata: "Salam, hai engkau yang dikaruniai, Tuhan menyertai engkau." Maria terkejut mendengar perkataan itu, lalu bertanya di dalam hatinya, apakah arti salam itu. Kata malaikat itu kepadanya: "Jangan takut, hai Maria, sebab engkau beroleh kasih karunia di hadapan Allah. Sesungguhnya engkau akan mengandung dan akan melahirkan seorang anak laki-laki dan hendaklah engkau menamai Dia Yesus. Ia akan menjadi besar dan akan disebut Anak Allah Yang Mahatinggi. Dan Tuhan Allah akan mengaruniakan kepada-Nya takhta Daud, bapa leluhur-Nya, dan Ia akan

22 Sean McDowell, Apologetics Study Bible for Students (Nashville: B\&H Publishing Group, 2010), 1002 menjadi raja atas kaum keturunan Yakub sampai selama-lamanya dan KerajaanNya tidak akan berkesudahan. " Kata Maria kepada malaikat itu: "Bagaimana hal itu mungkin terjadi, karena aku belum bersuami?" Jawab malaikat itu kepadanya: "Roh Kudus akan turun atasmu dan kuasa Allah Yang Mahatinggi akan menaungi engkau; sebab itu anak yang akan kaulahirkan itu akan disebut kudus, Anak Allah."

Kitab Suci memberikan fakta bahwa Yesus adalah satu-satunya keturunan perempuan yang tidak memiliki Bapa secara bilologis. Seans berpendapat bahwa: Yesus adalah penggenapan janji Mesiasik yang dinanti-nantikan dari generasi ke generasi. ${ }^{22}$ Beberapa bapak Gereja mulamula, seperti Justin Martyr (160 M) dan Irenaeus $(180 \mathrm{M})$, menganggap Kejadian 3:15 "sebagai Protoevangelium, ramalan mesianik pertama dalam Perjanjian Lama." ${ }^{23}$ Protevangelium adalah kata majemuk dari dua kata Yunani, $\pi \rho \tilde{\omega} \tau$ osprôtos yang berarti "pertama" dan $\varepsilon v ̉ \propto \gamma \gamma \varepsilon ́ \lambda ı v$ - euanggelion yang berarti "kabar baik" atau "Injil". Jadi protevanglium adalah penyebutan pertama dalam Alkitab tentang kabar baik

\footnotetext{
${ }^{23}$ Gordon J. Wenham, WBC: Genesis 1-15, (Thomas Nelson, 1987), hlm. 80-81.
} 
Jurnal Teologi \& Pelayanan ( Kerusso )

E-ISSN: 2714-9587

P-ISSN: 2407-554X

keselamatan". Alkitab memberi fakta aktual

bahwa keturunan Perempuan yang dimaksud dalam Kejadian 3:15 adalah merujuk kepada pribadi Yesus Kristus.

Banyak penafsir berpikir bahwa kemunculan ular di Kejadian 3, hanya bersifat simbolis yang sebenarnya menggambarkan setan yang sedang berbicara dalam hati Hawa. Namun penyelidikan dalam Kejadian 3:1, ular dibandingkan dengan binatang di darat lainnya yang diciptakan Tuhan. Jika binatang darat lainnya adalah sesuatu yang nyata, tentunya ularpun pasti sesuatu yang nyata dan bukan hanya sebatas simbolis. Demikian pula dalam ayat 13, Hawa mempersalahkan ular bukan iblis. Lebih lanjut dalam ayat 14, penghukuman terhadap ular dan keturunannya juga bersifat nyata, yaitu ular akan menjalar dengan perutnya dan debu tanah akan menjadi makanannya.

Kata Ibrani "nahas" (ular) adalah kata yang umum dipakai dalam bahasa Ibrani untuk merujuk pada ular (band. Bil. 21:7-9; Ul. 8:15; Ams. 23:32). Begitu pula dalam 2 Korintus 11:3, “Tetapi aku takut kalau-kalu pikiran kamu disesatkan dari kesetiaan kamu yang sejati kepada Kristus, sama seperti Hawa diperdaya oleh ular itu dengan kelicikkannya." Dalam bagian ini, Paulus mengingat kisah kejatuhan manusia dengan menyebut ular bukan iblis. Akan tetapi, dalam Alkitab juga setan dihubungkan dengan pembohong dan pembunuh sejak permulaan (Yoh. 8:44; 1 Yoh 3:18) dan setan juga dihubungkan dengan ular (Wahyu 12:9; 20:2). Dengan demikian, ular yang dimaksud dalam Kejdian 3 adalah nyata secara fisik, namun tindakannya untuk menggoda manusia tidak terjadi dengan sendirinya melainkan ada pengaruh dari luar yaitu Iblis. Hal ini dijelaskan oleh Lasor. Ayat 15a menempatkan ular berlawanan dengan perempuan dan keturunan ular berlawanan dengan keturunan perempuan. Tetapi ayat $15 \mathrm{~b}$ menempatkan keturunan perempuan berlawanan dengan ular itu sendiri, bukan dengan keturunan ular. ${ }^{24}$ Dilihat dari frasa katanya, memberi indikasi bahwa "ular yang bermusuhan dengan keturunan perumpuan adalah iblis itu sendiri” yang telah memperalat ular sebagai sarananya untuk menjatuhkan manusia.

PENGGENAPAN JANJI KESELAMATAN DALAM KEJADIAN

\section{$3: 15$}

Berdasarkan kajian sebelumnya

${ }^{24}$ W.S. Lasor, D.A. Hubbard, F.W. Bush, Pengantar Perjanjian Lama 1 Taurat dan Sejarah (Jakarta: BPK Gunung Mulia, 2011), 127-128 
telah diketahui bahwa frasa "keturunan perempuan" yang dimaksud dalam Kejadian 3 adalah merujuk kepada pribadi Yesus yang dilahirkan oleh benih wanita dan tidak memiliki bapa secara biologis. Sedangkan frasa "ular yang mengalahkan keturunan perempuan" adalah merujuk pada iblis. Beralih pada polemik teologis sebelumnya, telah dianggap bahwa konsep keselamatan manusia dalam dosa merupakan sebuah pertandingan antara Allah dan Iblis. Akibatnya, para pemikir berpandangan bahwa keselamatan manusia merupakan hasil rebutan Allah dari Iblis. Pandangan semacam ini perlu penyelidikan.

\section{Penyaliban Yesus: Iblis Meremukkan Tumit Benih Wanita}

Kejatuhan manusia dalam dosa, tidak bisa menggagalkan kedaulatan Allah. Setelah protoevanglion disampaikan oleh Allah sendiri dalam Kejadian 3:15, Perjanjian Lama terus mengulangi tema ini bahwa suatu hari kelak Juruselamat akan datang ke dunia untuk membebaskan umat manusia. Rencana Allah bagi kepentingan manusia diungkapkan-Nya melalui penebus yaitu benih wanita yang akan membawa keselamatan (Yesaya 7:14; Matius 1:16). Perjanjian ini dipegang dan dipelihara oleh
Allah dari zaman ke zaman termasuk di Perjanjian Lama. Janji Allah sungguhsungguh menjadi kenyataan. Firman menjadi manusia yang dilahirkan oleh benih wanita dalam pribadi Yesus Kristus (Yohanes 1:14,29).

Penderitaan Yesus melalui salib merupakan bukti permusuhan iblis yang begitu hebat dengan keturunan perempuan. Nubuatan Kitab Kejadian 3:15 dalam frasa "ular akan meremukkan tumit benih wanita" tergenapi melalui kematian Yesus di kayu salib. Perlu diketahui bahwa setelah kabar baik disampaikan oleh Allah dalam Kitab Kejadian 3, Perjanjian Lama terus mengulangi tema ini dan terus menubuatkan tentang kehidupan keturunan perempuan yang dimaksud. Dinubuatkan tentang kelahiranNya, penderitaanNya dan juga tentang kematianNya. Semua nubuatan dalam Perjanjian Lama tentang penderitaanNya terpenuhi. Hal ini dijelaskan oleh Paul Enns bahwa: Keturunan perempuan itu akan diremukkan tumit-Nya oleh ular yang menjelaskan tentang penderitaan dan sengsara yang akan ditanggung olehNya ${ }^{25}$

Alkitab mencatat tentang pemukulan yang dialamiNya, "Lalu mereka meludahi muka-Nya dan meninju-Nya; orang-orang

\footnotetext{
${ }^{25}$ Paul Enns, Buku Pegangan Teologi, disunting oleh Nicholas Kurniawan, dkk (Malang: Literatur SAAT, 2004), 47
} 
Jurnal Teologi \& Pelayanan ( Kerusso )

E-ISSN: 2714-9587

P-ISSN: 2407-554X

lain memukul Dia" (Matius 26:67; Band. Yesaya 50:6). Begitu pula dengan Ejekan yang dinubuatkan dalam Mazmur 22:8-9 tentang diriNya, tergenapi Matius 27:31: "Sesudah mengolok-olokkan Dia mereka menanggalkan jubah itu daripadaNya dan mengenakan pula pakaianNya kepada-Nya.

Kemudian mereka membawa Dia ke luar untuk disalibkan." Peristiwa membagibagikan pakaianNya Kitab Suci Perjanjian Lama telah mengkonfirmasi (Maz. 22:19). Hal lainnya tentang Dia yang diramalkan dalam Perjanjian Lama adalah bahwa Ia akan tertimpa salib (Maz. 109:24-25) yang kemudian hal ini terpenuhi dalam Lukas 23:26: "Ketika mereka membawa Yesus, mereka menahan seorang yang bernama Simon dari Kirene, yang baru datang dari luar kota, lalu diletakkan salib itu di atas bahunya, supaya dipikulnya sambil mengikuti Yesus." Yesus yang begitu lemah memikul salib, membuat lututNya tidak kuat dan orang yang menyalibkanNya terpaksa menyuruh orang lain membawakannya untuk Dia. Berkaitan dengan penyalibanNya yang menjadi tontonan banyak orang (Lukas 23:35), jauh sebelumnya Mazmur 22:18 telah memberitahunya.

Begitu pula dengan tangan dan

\footnotetext{
${ }^{26}$ Josef Blinzler, The Trial Jesus. Diterjemahkan oleh Isabel dan Florence (Westminster: The Newman Press, 1959), 248
}

kakiNya yang ditusuk, Perjanjian Lama telah menubuatkannya (Maz. 22:17; Zakh. 12:10) dimana hal ini tergenapi dalam Lukas 23:33 dan Yohanes 20:25. Kemudian berkaitan dengan penyalibanNya bersama penjahat dalam Nubuat Yesaya53:12 terbukti dalam Matius 27:38: "Bersama dengan Dia disalibkan dua orang penyamun, seorang di sebelah kanan dan seorang di sebelah kiriNya." Blinzler mengonfirmasi bahwa: orang-orang Yahudi pada zaman Yesus mengganggap orang yang dihukum mati dengan cara disalib adalah orang yang paling terkutuk oleh Allah. ${ }^{26}$

Ketika Yesus di kayu salib mengalami kehausan (Yoh. 19:28; Band. Maz. 22:16; 69:2) dan pada akhirnya Dia diberi minum anggur bercampur empedu (Mat. 27:34) dan bercampur mur (Mar. 15:23; Band. Maz. 69:22). Ada kemungkinan Matius mengartikan bahwa anggur itu bercampur empedu sedangkan menurut Markus anggur itu bercampur mur. Kemudian bisa juga keduanya diberikan kepada Yesus dalam peristiwa penyaliban ini. Namun Alkitab mencatat bahwa Yesus menolaknya.

Ketika Yesus disalib, "orang-orang yang lewat di sana menghujat Dia dan sambil menggelengkan kepala" (Mat. 
27:39) dimana hal ini telah disampaikan sebelumnya dalam Mazmur 22:8; 109:25. Menurut Targum Yahudi, menggelengkan kepala merupakan "Suatu bahasa tubuh yang menyiratkan bahwa bagi sang pendenta sudah tidak ada harapan lagi, dan oleh karenanya mereka mencemooh dan memandangnya dengan hina."27

Semua nubuatan perjanjian lama dan pemenuhannya dalam perjanjian Baru tentang penderitaan Yesus merupakan bukti permusuhan antara iblis dan benih wanita. Dosa manusia yang diakibatkan oleh godaan iblis mengakibatkan Yesus menderita dan mati di kayu salib. Ini merupakan fakta aktual bahwa blis meremukkan tumit benih wanita (Kej. 3:15; band. Yes. 53:10a). Dalam Kitab Suci tertulis, "Dia yang tidak mengenal dosa telah dibuatnya menjadi dosa karena kita, supaya dalam Dia kita kita dibenarkan oleh Allah" (II Kor. 5:21). Dengan kata lain, kematian Yesus bukan karena Dia berdosa melainkan untuk menggantikan manusia menanggung hukuman maut.

\section{Kematian dan Kebangkitan Yesus Meremukkan Kepala Iblis}

Telah diketahui bahwa penyaliban

\footnotetext{
27 J.W. Ethridge, The Targums of Onkelos and Jonathan Ben Ussiel on the Pentateukh, Vol. 1,2. (Newyork: KTAV Publishing House, 1968), 148

${ }^{28}$ Paul Enns, Buku Pegangan Teologi, 47
}

Kristus merupaka penggenapan terhadap pernyataan Allah bahwa "iblis akan meremukkan tumit benih wanita". Namun tidak cukup sampai di situ, semuanya harus tergenapi. Yesus berkata: "Inilah perkataanku yang telah Kukatakan kepadamu, ketika Aku masih bersama-sama kamu yakni bahwa harus digenapi semua yang ada tertulis tentang Aku dalam kitab Taurat Musa dan kitab Nabi-nabi dan kitab Mazmur” (Lukas 24:44). Kebangkitan Yesus membuktikan kemenanganNya dalam pertempuran mengalahkan iblis. Paul Enns berpendapat bahwa "Keturunan perempuan akan meremukkan kepala ular diyakini sebagai nubuatan akan kekalahan Setan dan kuasa maut". ${ }^{28}$ Peristiwa kebangkitan Yesus merupakan bukti nyata bahwa Yesus telah mengalahkan iblis, dosa dan kuasa maut.

Sebelum melihat bukti-bukti kebangkitan Yesus dalam Alkitab, ada beberapa pandangan yang menyanggah kebangkitan Yesus. Ada yang berdalil bahwa Yesus tidak benar-benar bangkit dan hal ini menjadi kontroversi yang masih diguncingkan hingga saat ini. ${ }^{29}$ Ada pula yang berkata bahwa Yesus bukan hanya sungguh-sungguh mati tetapi juga Ia

29 Adji A. Sutama, Yesus Tidak Bangkit (Jakarta: BPK Gunung Mulia) 196-197 
Jurnal Teologi \& Pelayanan ( Kerusso )

E-ISSN: 2714-9587

P-ISSN: 2407-554X

bangkit dengan tubuh fisik yang sama ketika Ia mati. ${ }^{30}$ Jika Kristus tidak bangkit, kuasa iblis, dosa dan kematian tetap tidak terkalahkan. Dengan kata lain, kematian Kristus di kayu salib menjadi tidak berarti bila Dia tidak benar-benar bangikit. Berikut ini merupakan bukti kebangkitan Yesus mengalahkan iblis, dosa dan kematian:

Nubuatan Alkitab dan Penggenapannya. Dalam Alkitab Perjanjian Lama telah disampaikan bahwa "sebab Engkau tidak menyerahkan aku ke dunia orang mati, dan tidak membiarkan orang-orang kudus-Mu melihat kebinasaan (Maz. 16:10." Kebangkitan Kristus dari antara orang mati merupakan penggenapan dari nubuatan ini. Demikian juga dalam Kitab Yesaya telah tertulis bahwa "Apa bila ia menyerahkan dirinya sebagai korban penebus salah, ia akan melihat keturunannya, umurnya akan lanjut, dan kehendak TUHAN akan terlaksana olehnya (Yes.53:10b)”. Diyakini bahwa ayat ini terpenuhi melalui Kristus yang telah menyerahkan diriNya mati di salib sebagai korban penghapus dosa manusia. Kristus yang telah bangkit dari

\footnotetext{
${ }^{30}$ Norman Geisler, Ketika Alkitab Dipertanyakan (Yogyakarta: ANDI, 2006), 142

31 Ketika para pemuka agama Yahudi mengingat perkataan Yesus bahwa Ia akan bangkit pada hari ke tiga, mereka minta agar Pilatus memerintahkan untuk memberikan penjagaan yang ketat dengan kubur Yesus. Tokoh Yahudi ini, mengkhawatrkan kubur Yesus agar tidak dicuri oleh Murid-murid Yesus dan berkata Yesus sudah bangkit. Hal ini
}

antar orang mati, terus melihat orang-orang yang diselamatkan. Demikian juga di dalam Kitab Perjanjian Baru, Yesus semasa hidupNya telah memberitahukan bahwa Ia akan bangkit setelah mati (Mat. 12:40; Mat. 16:21; Mat. 17:9; Mat. 17:23; Mat. 26:32). Fakta-faktanya;

Pertama, adanya Para Penjaga Kubur. Pada kajian sebelumnya memberi esay bahwa Yesus benar-benar mati di kayu salib. Tokoh agama Yahudi sangat khawatir jika para murid akan mencuri mayat Yesus dan menyebarkan kisah kebangkitan palsu. Kecemasan mereka dengan hal ini, mereka mendesak pontius Pilatus (Gubernur Yudaea) untuk menunjuk para penjaga untuk mengawasi kubur yang sudah dimeterai selama tiga hari (Mat. 27:6266). ${ }^{31}$ Para penjaga terkejut oleh gempa bumi dan kehadiran Malaikat Tuhan yang menggulingkan batu. Para pengawas kubur mengetahui bahwa sesuatu yang tidak alamiah terjadi dan tidak ada kebohongan yang bisa mengubah fakta, Yesus bangkit dari kematian (Mat. 27:65; 28:4).

Kedua, kubur Kosong. Ketika murid-

direspon baik oleh Pilatus, sehingga ia berkata pada mereka: "Ini penjaga-penjaga bagimu, pergi dan jagalah kubur itu sebaik-baiknya." Maka pergilah mereka dan dengan bantuan penjaga-penjaga itu mereka memeterai kubur itu dan menjaganya (Matius 27:62-66). Jadi, Meterai dan penjagaan yang sangat ketat terhadap kubur Yesus, akan membantahkan dugaan sebagian orang yang berpikir bahwa kubur Yesus dicuri oleh murid-murid 
murid datang ke kubur pada pada hari pertama minggu itu, kubur tersebut kosong. Para murid terkejut sama seperti orang lainnya (Mat. 27:57-60; Mar. 15:42-47; Luk. 23:50-53; Yoh. 19:38-41). Berkaitan dengan kubur yang kosong, ada beberapa hal yang harus dipertimbangkan. Pertama, Para murid adalah orang-orang Yahudi dan sangat terikat pada hukum-hukum Allah, moral sipil dan upacara. Salah satu hukum upacara adalah mengenai "menyentuh tubuh orang mati”. Siapapun yang melakukan hal ini dianggap tercemari dan najis (Band. Bil. 19:11-12). Bila para murid memegang mayat Yesus, harus memenuhi hukum upacara pentahiran. Kedua: Akibat kematian Yesus, para murid sangat ketakutan dan tentunya hal ini tidak mungkin mereka berani untuk merusak kubur yang sudah dimeterai dan mencuri tubuh Yesus yang sudah dijaga dengan ketat oleh penjaga-penjaga kubur. Jawaban dari misteri hilangnya tubuh Yesus adalah kebangkitanNya (KPR. 2:24-32) ${ }^{32}$ Josh McDowell menjelaskan bahwa "Melihat cara pengamanan kubur Yesus yang seperti itu, meterai Romawi yang dipasang di sana dimasukkan untuk mencegah segala macam usaha untuk merusakkan makam itu. Siapapun yang berusaha memindahkan batu itu dari depan pintu kubur itu berarti

${ }^{32}$ Kevin Conner J, A Practical Guide to Christian Bilief (Malang: Gandum Mas, 2004), 510 membangkitkan murka hukum Romawi. ${ }^{33}$ Alkitab menjelaskan bahwa Malaikat Tuhanlah yang merusak meterai pada kubur itu menggulingkan batu (Mat. 28:2).

Ketiga, kesaksian Banyak Orang. Selama empat puluh hari mulai dari kebangkitan Yesus hingga kenaikanNya ke surga, Yesus berulangkali menampakkan diri kepada banyak orang. Ia menampakkan diri kepada Maria Magdalena, Maria Ibu Yakobus dan Salome (Mar. 16:9; Yoh. 20:11-18), Petrus (Mat. 28:9; Mar. 16:7; Luk. 24:1), Yakobus (1 Kor. 15:7), Para murid tanpa kehadiran Tomas (Yoh. 20:1923), para murid dan Tomas (Yoh. 20:2429), dua orang ke Emaus (Mar. 16:12-13; Luk. 24:13-35) dan kepada lima ratus orang percaya (1 Kor. 15:6). Beralih pada peristiwa setelah kenaikan Yesus ke sorga; Ia manampakkan diri kepada Stefanus (KPR. 7:54), Paulus (KPR. 9:1-7; 22:9; 26:16-18; 1 Kor. 15:8; Gal. 1:11-18), Yohanes murid Yesus (Wah. 1:7, 10-16). Kesaksian para saksi yang telah melihat Yesus setelah kebangkitanNya menyuguhkan pembuktian.Keempat, kain Peluh Pembungkus Kepala Yesus. Kain peluh yang dipakai untuk membungkus kepala Tuhan Yesus terlipat di suatu tempat dengan sendirinya. Tentu ada yang telah merapikannya. Sangat tidak mungkin para

\footnotetext{
${ }^{33}$ Josh McDowell, Apologetika: Bukti Yang Meneguhkan Kebenaran Alkitab, 323-324
} 
Jurnal Teologi \& Pelayanan ( Kerusso )

E-ISSN: 2714-9587

P-ISSN: 2407-554X

penjaga dan para murid yang

bahkan sampai mati demi Tuhan Yesus. Ini

melakukannya. Ini fakta bahwa Yesus telah

bangkit (Yoh. 20:7).

Kelima, Kain Kafan. Bukti lainnya tentang kebangkitan Yesus adalah kain kafan yang dipakai untuk membungkus tubuh Yesus. Petrus dan Yohanes masuk ke dalam kubur dan melihat kain kafan masih utuh dalam bentuk asli namun tidak terbuka tetapi tubuh Yesus tidak ada. KebakingkitanNya merupakan jawaban atas kain kafan yang masih utuh (Yoh. 20:6).

Keenam, Perubahan Signifikan Para Murid. Setelah peristwa penyaliban dan kematian Yesus, para murid serta pengkutpengikutNya menjadi sangat takut, sedih, cemas dan tidak tau apa yang hendak dilakukan. Ketakutan mereka terhadap serangan orang Yahudi membuat mereka berhimpun di suatu tempat dan mengunci pintu-pintu. Hal ini membuktikan bahwa mereka tidak yakin kalau Yesus yang mati telah bangkit kembali. Akan tetapi, setelah Tuhan yesus menampakkan diri, mereka percaya dan dengan penuh semangat memberitakan Injil. Perjumpaan muridmurid kepada Yesus setelah kebangkitan, membuat mereka berubah secara signifikan

\footnotetext{
34 Tony Evans, Who Is This King Of Glory (Batam: Gospel Press, 2005), 89

${ }^{35}$ Elmer Towns, Inti Kekristenan: Apa Sebenarnya Kekristenan Itu (Jakarta, Penerbit Nafiri Gabriel, 2011), 45
} semua merupakan bukti bahwa kebangkitan Tuhan Yesus bukan hanya sebatas khayalan, melainkan benar adanya. Para pendiri agama lain mati dan tetap berada di dalam kubur, tidak demikian halnya dengan Kristus. Setelah mati dan dikuburkan, Ia hidup kembali dan mengalahkah keluar dari makamnya pada hari ketiga. ${ }^{34}$ Kekristenan merupakan satu-satunya agama di dunia yang menegaskan bahwa pendirinya tidak hanya mati bagi orang lain, tetapi juga bangkit kembali secara jasmani dari kematian. ${ }^{35}$

\section{Konsep Tebusan Yesus dalam}

\section{Keselamatan}

Kata untuk penebusan dalam Perjanjian Lama adalah hd'P'. ${ }^{36}$ Kata ini memiliki arti mengangkat sesuatu atau seseorang keluar dari kepemilikan seseorang untuk menjadi miliknya, dengan memberikan sesuatu yang sepadan (Kel. 13:13; Ay. 6:22). Hal ini dilakukan oleh Allah semenjak memilih bangsa Israel sebagai umat pilihan. Alasan untuk penebusan ini adalah untuk menunjukkan kasih sayang Allah (Maz. 44:26; 2 Sam.

\footnotetext{
36 Ludwig Kohler, Old Testament Theology (Philadelphia: The Westminster Press, 1957), 233
} 
7:23; 1 Taw. 17:21). Ada tiga tahap penyelamatan Allah melalui penebusan bagi bangsa ini. Pertama, pada waktu keluarnya bangsa Israel dari dari perbudakan Mesir, kedua secara terus-menerus dalam kehidupan orang-orang kudus-Nya (2 Sam. 4:9; Yer. 15:21; Ay. 5:20) dan yang ketiga akan dinyatakan pada hari keselamatan tiba (Maz. 130:8). Kata lainnya untuk penebusan adalah la;G". ${ }^{37}$ Pengertian dari kata ini adalah melakukan suatu tugas sebagai penebus, dimana darah telah dicurahkan.

Janji akan penebusan pertama sekali dipenuhi dalam peristiwa Keluaran. ${ }^{38}$ Pembuangan dan penyebaran bangsa Israel keseluruh dunia akan diiukuti oleh hari penyelamatan. Namun ada beberapa tahap sebelum hari kedatangan-Nya tiba. Hanya sisa-sisa Israel yang akan ditebus. Sisa-sisa ini disebukan oleh Amos, dan juga mendapat penambahan penting dalam kitab Yesaya. Dalam sisa-sisa ini, akan muncul tunas baru dari pohon tua yang sudah jatuh, suatu tunas yang kudus (Yesaya 6:13). Inti dari semua ini adalah pengharapan akan kedatangan seorang Mesianik yang akan menyelamatkan.

Manusia tidak dapat melakukan apa-

\footnotetext{
37 Kohler, Old Testament Theology (Philadelphia: The Westminster Press, 1957), 234

${ }^{38}$ Ludwig Kohler, Old Testament Theology, 235
}

apa untuk menambah karya Kristus. Jika manusia dapat mencapai Allah melaiui suatu jalan lain, Yesus tidak harus mati di kayu salib. Kematian Kristus menjadi fakta bahwa tidak ada jalan di luar Yesus untuk memperoleh keselamatan. Dengan demikian, keselamatan sepenuhnya adalah karya Allah. Ketidakberubahan rancangan Tuhan menyatakan kuasa kekal dan keilahian-Nya (Mazmur 33:9-11). ${ }^{39}$

Pada bagian sebelumnya telah dipaparkan secara luas hubungan keselamatan dengan janji Allah dalam "Frasa keturunan perempuan mengalahkan iblis". Kematian Yesus di kayu salib merupakan penggenapan tentang iblis yang mematok tumit benih wanita. Sedangkan penggenapan tentang keturunan perempuan yang mengalahkan iblis, telah terpenuhi melalui ketaatan Yesus pada salib dan kebangkitanNya dari kematian.

Beralih pada dilema teologis sebelumnya. Melihat penderitaan Kristus yang tiada taranya untuk mengalahkan iblis mengakibatkan para pemkir berpendapat bahwa "keselamatan manusia merupakan hasil rebutan Allah pada iblis". Hal mendasar yang harus diketahui untuk mempertimbangkan pendapat ini adalah

\footnotetext{
39 John Owen, Christians Are Forever (Surabaya: Momentum 2005,) 13
} 
dengan melihat sifat Allah yang Maha Adil (Ul. 32:4; 1Yoh. 1:9) dan Maha Kasih (Kel. 34:6; Ul. 4:31; 2 Taw. 30:9; Mazm. 103:8; 145:8; Yoel. 2:13; Yoh. 3:16; Rom. 5:8; 1Yoh. 4:8). Melalui peristiwa kejatuhan manusia di taman eden, sifat Keadilan dan kasih Allah sungguh terbukti. Ketika Tuhan mengetahui bahwa manusia sudah jatuh dalam dosa, dengan inisiatifNya sendiri mencari dan menemukan manusia. Bukan Adam dan Hawa yang mencari Tuhan, melainkan Tuhanlah yang mencarinya. Sesaat setelah Allah menemukan mereka, Dia menyatakan hukuman dan juga menjanjikan keselamatan melalui benih wanita (Kej. 3:15).

Allah membenci dosa oleh karen sifat kekudusaNya dan menghukum setiap pendosa berdasarkan keadilaNya. Sebelum kejatuhan manusia dalam dosa, Tuhan sudah memberi peringatan kepada manusia bahwa akibat pelanggaran akan dihukum kematian. Allah tidak berubah, hukuman kematian berlaku pada manusia (Kej. 2:17). John Joseph Owens menjelaskan: Allah bersumpah demi kekudusan-Nya, karena kekudusan merupakan ungkapan yang paling penuh dari sifat-sifat-Nya, melalui kekudusan menjelaskan sepenuhnya keberadaan-Nya dan yang membedakan Ia

\footnotetext{
${ }^{40}$ John Joseph Owens, Analytical Key Tho The Old Testament Volume 4 (Michigan: Baker Book House, 1996) 151
}

dengan ciptaan-Nya. ${ }^{40}$ Sedangakan J.I. Packer berpendapat: "keselamatan manusia dari dosa dan murka Allah adalah inisiatif Allah yang murah hati sejak permulaan zaman (II Timotius 1:9) dan dibawa dijalankan-Nya di dalam sejarah menurut rencana dan panggilan-Nya berdasarkan kemurahan-Nya (Roma 8:30)." ${ }^{41}$

Penggenapan janji Allah untuk keselamatan manusia, semua tergenapi di dalam Yesus Kristus yang bersedia menjadi korban untuk orang berdosa. Ketika Tuhan memaafkan tanpa menghukum melanggar prinsip keadilan Allah, akan tetapi menghukum tanpa memaafkan melanggar prinsip kasih setia-Nya. Ini merupakan alasan Allah datang ke dunia dalam rupa manusia dalam pribadi Yesus. Ia disalibkan hingga mati menebus dosa manusia. Firman Tuhan berkata: "Karena begitu besar kasih Allah akan dunia ini, sehingga Ia telah mengaruniakan Anak-Nya yang tunggal. Supaya setiap orang yang percaya kepadaNya tidak binasa, melainkan beroleh hidup yang kekal (Yohanes 3:16)." Kritus yang telah datang ke dunia membawa misi kasih, demi mendamaikan manusia dengan Allah. Yesus datang menyerahkan diri-Nya menderita hingga mati disalib dengan tujuan untuk menebus dan menyelamatkan

\footnotetext{
${ }^{41}$ J.I. Packer, Key Bible Themes Studies of Key Bible Themes (Grand Rapids Baker, 1981) 94
} 
manusia yang dikasihi-Nya. Hutang dosa manusia dibayar lunas melalui pengorbanaNya di kayu salib. Pembayaran ini tidak dibayarkan untuk setan, tetapi untuk Tuhan. Hutang yang dihapuskan adalah hutang kepada sifat Allah yang maha adil. Setan tidak berhak untuk orang berdosa, dan juga tidak memerlukan pembayaran supaya orang berdosa menjadi bebas. $^{42}$ Keselamatan yang Tuhan rancang sedemikian baiknya tidak pernah dilakukan karena ancaman siapapun. Martin Luther berpendapat bahwa, Penebusan Kristus dalam tubuh adalah menurut kehendak Allah dan merupakan cara Allah untuk menyelamatkan manusia (Ibrani 10:7, 9,19, 20). ${ }^{43}$ Tuhan berkuasa atas semua ciptaanNya termasuk untuk neraka tempat iblis dan orang berdosa dihukum. Allah tetap menyatakan hukuman bagi manusia yaitu "hukuman maut". Hal ini tidak bisa dibatalkan karena bertentangan dengan sifat kekudusan dan keadilan-Nya. Namun oleh karena kasih-Nya yang begitu hebat bagi manusia (Yohanes 3:16), Allah sendiri yang adalah Firman (Yohanes 1:1) telah menjadi manusia (Yohanes 1:14) dan mati di kayu salib (Filipi 2:8) menghapus dosa manusia

\footnotetext{
${ }^{42}$ Chris Marantika, Doktrin Keselamatan dan Kehidupan Rohani (Yogyakarta: Iman Press, 2002) 72-73

${ }^{43}$ Dr. Peter Wongso, Soteriologi (Doktrin Keselamatan) (Malang: Seminari Alkitab Asia Tenggara, 1998) 26
}

(1 Yohanes 3:5). Yesus berkata: “Akulah jalan dan kebenaran dan hidup. Tidak ada seorang pun yang datang kepada Bapa, kalau tidak melalui Aku (Yoh. 14:6). Berdasarkan penyelidikan ini, Pandangan yang menuduh keselamatan manusia merupakan hasil rebutan Allah dari iblis patut dieliminasi.

\section{Yesus Kristus dalam Penggenapan Janji Keselamatan}

Penyelidikan dalam Perjanjian Lama, konsep keselamatan memiliki makna yang sangat luas. Penyelamatan yang dimaksud bersifat: pribadi dan social, rohani dan jasmani, politis dan ekonomis, manusiawi dan ekologis, lokal dan kosmik, Sekarang dan Esok. ${ }^{44}$ Foaster menjelaskan alasan mengapa demikian. Menurutnya dalam Perjanjian Lama, "Manusia terancam bahaya, musibah fisik, penganiayaan oleh lawan dan kematian." ${ }^{45}$ Sehingga kebutuhan akan keselamatan bukan hanya tentang kehidupan kekal setelah kematian melainkan juga keselamatan secara fisik selama masih ada di dunia. Inti dalam Perjanjian Lama secara keseluruhan menunjukkan betapa besarnya kebutuhan

\footnotetext{
${ }^{44}$ Christ Wright, Tuhan Yesus memang khas dan unik (Jakarta: Yayasan Bina Kasih OMF, 2003), 52

${ }^{45}$ W. Foaster dkk, “Keselamatan” dalam Ensiklopedi Alkitab Masa Kini, J. D Douglas, penyunting (Jakarta: Yayasan Bina Kasih OMF, 2007)
} 
Jurnal Teologi \& Pelayanan ( Kerusso )

E-ISSN: 2714-9587

P-ISSN: 2407-554X

keselamatan akibat dosa manusia.

Penyelidikan dalam historis

Perjanjian Lama menyungguhkan bahwa janji Allah atas keselamatan manusia terbukti dan terpelihara hingga tergenapi di dalam diri Yesus. Paul Enns menjelaskan secara sistematis. Menurutnya, berawal dari akibat dosa manusia di Eden yang telah melakukan dosa akhirnya Tuhan menghukum mereka, lalu Allah menyatakan, Ia mengadakan permusuhan antara setan dengan manusia, inilah yang disebut dengan protevangelium (Kejadian 3:15), menunjuk pada kemenangan Kristus di kayu salib (Kolose 2:14; Ibrani 2:14). ${ }^{46}$

Pembuktikan tentang konsistensi Allah dalam penggenapan janji pada Adam, terlihat dalam tindakanNya melalui historis keberadaan manusia dari zaman Perjanjian Lama. Melihat pada zamannya Nuh. Pada zaman ini perbuatan dosa manusia sudah merejalela sehingga Allah menghukum seisi dunia dengan mendatangkan air bah (Kej. 6). Namun di tengah kefasikan dan kejahatan itu, Allah menemukan Nuh seorang yang benar dan hidup bergaul denganNya. Keberadaan Nuh yang "Tidak bercela di antara orang-orang sezamannya" menunjukkan bahwa dia memisahkan diri

\footnotetext{
${ }^{46}$ Paul Eens, The Moody Hand Book of Theology 1 (Malang: Literatur SAAT, 2008) 47

${ }^{47}$ Chris Marantika, Eskatologi (Yogyakarta: Iman Press, 2007) 20-21
}

dari kejahatan moral masyarakat di sekitarnya. Nuh berkenan kepada Allah (Kej. 6:8; 7:1; Ibr. 11:7; 2 Pet. 2:5) oleh iman dan pergaulannya dengan Allah (Kej. 6:9). Kemurahan dan kasih karunia Allah yang diterima Nuh oleh karena imannya, menghasilkan usaha yang tulus untuk hidup terpisah dari angkatan yang jahat (Kej. 6:22; Kej. 7:5, 9, 16; Ibr. 11:7). Setelah peristiwa air bah Tuhan berjanji pada pada Nuh. Janji Allah tidak akan mendatangkan air bah lagi (Kej. 9:11) dan sebagai tanda perjanjian itu adalah busur Tuhan yaitu pelangi. $^{47}$

Kemudian pada zaman Abraham. Dalam Perjanjian Lama, Allah menggambarkan rencana-Nya bagi penyelamatan umat manusia melalui pemilihan Bangsa Israel. Hal ini dimulai dengan panggilan Allah kepada Abraham. Tuhan memberikan empat berkat yaitu berkat pribadi, berkat teritorial atau wilayah, berkat nasional, dan yang terakhir berkat spritual yang hubungannya dalam Galatia 3:14, yaitu ada berkat bagi bangsabangsa kafir melalui Yesus Kristus. Christ menegaskan bahwa "Allah memilih secara khusus bangsa Israel untuk menyatakan berkat keselamatan bagi semua bangsa. $" 48$

\footnotetext{
${ }^{48}$ Christ Wright, Tuhan Yesus memang khas dan unik (Jakarta: Yayasan Bina Kasih OMF, 2003), 5666
} 
Berlanjut pada pendiri negara Israel yaitu Musa. Allah memberikan Taurat sebagai curahan hatiNya yang bertujuan supaya Bangsa Israel mengikuti ketetapanketetapanNya seperti dalam Keluaran 19:45 dan Ulangan 26:16-19. Pada zaman ini, Allah membuat perjanjian untuk bangsa Israel yang dikenal sebagai convenan Musa. Hukum itu dibagikan dalam tiga kategori yaitu hukum Sipil, hukum Seremonial dan hukum Moral. Hukum Moral terdapat dalam sepuluh hukum (Kel. 20:2-17; Ul. 5:6-21), hukum Sipil meliputi hukum di Kitab Keluaran 21:1-24:18, dan hukum Seremonial terdapat di dalam Kitab Keluaran 25:1-40:38 yang meliputi tabernakel, pakaian, fungsi dari imam, korban-korban dan persembahan. Ternyata pemberian hukum bagi bangsa Israel tidak memberikan suatu perubahan yang fundamental dalam kehidupan mereka. Banyak diantara kaum Israel yang gagal melihat tujuan pemberian hukum itu. Orang Israel seringkali memiliki konsep yang salah dengan melihat hukum sebagai cara legalistic dan berusaha mendasarkan klaim mereka akan keselamatan pada pemenuhan cara hidup... ${ }^{49}$ Ketaatan kepada hukum dalam Perjanjian Lama tidak berarti

\footnotetext{
${ }^{49}$ Louis Berkof, Teologi Sistematika: Doktrin Keselamatan, Yudha Thianto, Penerjemah (Surabaya: Momentum, 2006), 191-192

${ }^{50}$ Claus Westerman, Elements Of Old Testament Theology (Atlanta: John Knox Press, 1978), 179
}

bertentangan dengan konsep keselamataa dalam Perjanjian Baru. Dalam Perjanjian Lama sendiri, ketaatan kepada hukum tidak pernah dipahami sebagai jalan keselamatan. Ketaatan terhadap hukum taurat dan perintah Allah lebih ditujukan sebagai sumber berkat Allah, secara khusus dalam kitab Ulangan, tetapi tidak pernah sebagai landasan bagi penyelamatan Allah. ${ }^{50}$ Bahkan pada zaman hukum ini, iman jelas bersifat soteorologis dan mereka mencari keselamatan dalam Mesias. Iman berupa kepercayaan kepada Tuhan yang memberikan keselamatan dan suatu kepercayaan yang bersandar teguh pada janji-janji-Nya untuk masa yang akan datang. ${ }^{51}$

Setelah Perjanjian dengan Musa, Allah membuat Perjanjian kepada Daud bahwa keturunannya akan memerintah di dalam kerajaan yang kokoh, tidak tergoyahkan dan bersifat kekal untuk selama-lamanya (2 Sam. 7:16). Kemudian Allah membuat perjanjian convenan dengan nabi-nabiNya melalui Yesaya sampai kepada nabi Zakharia. Dalam Kitab Yesaya 4:2 berbunyi: "Pada waktu itu tunas yang ditumbuhkan TUHAN akan menjadi kepermaian dan kemuliaan, dan hasil tanah

\footnotetext{
${ }^{51}$ Louis Berkof, Teologi Sistematika: Doktrin Keselamatan, Yudha Thianto, Penerjemah (Surabaya: Momentum, 2006), 192
} 
Jurnal Teologi \& Pelayanan ( Kerusso )

E-ISSN: 2714-9587

P-ISSN: 2407-554X

menjadi kebanggaan dan kehormatan bagi orang-orang Israel yang terluput." Frasa "tunas yang ditumbuhkan Tuhan" dalam ayat ini diyakini merujuk kepada sebutan bagi Mesias (yaitu Kristus). Ia akan tampil sebagai Tunas Daud (Yes. 11:1; 53:2; Yer. 23:5; 33:15; Za. 3:8; 6:12; Rom. 15:12; Wahy. 5:5; 22:16). Ayat ini mengacu kepada saat hukuman dan keselamatan, yaitu saat ketika Kristus akan memerintah di atas sisa umat-Nya yang setia di Yerusalem (Yes 4:4) dan memelihara mereka dengan perhatian dan kasih yang besar (Yes. 38:58,15-17; Yes. 65:18). Kemudian kepada Nabi Yehezkiel, Allah berjanji untuk membuat ibadah yang baru untuk mendemonstrasikan kekudusan Allah, menyediakan pusat pemerintahan ilahi, menyediakan kemenangan atas kutuk. Di dalam Kitab Daniel Allah menyatakan kedaulatan untuk melakukan apa yang dikehendaki-Nya. Kemudian beralih pada Perjanjian yang baru yaitu tentang umat yang berwaspada akan hari Tuhan. Di Zaman nabi Zakharia bercerita tentang antisipasi kedatangan Tuhan dan pada akhirnya semua master plan Allah diwujudkan di dalam Yesus Kristus yang menyelamatkan manusia berdosa melalui pengorbanan-Nya di kayu salib. Yesus

\footnotetext{
${ }^{52}$ Horst Dietrich Preuss, Ol Testament Theology, Volume II (Kentucky, Westminster John Knox Press, 1992), 35-36
}

melanjutkan pemerintaha-Nya pada kedatangan-Nya kedua kali.

Sejarah Keselamatan berkembang dalam sepanjang sejarah iman dalam Perjanjian Lama sampai akhirnya mereka berfokus pada tujuan akhir, yaitu pengharapan eskatologikal, Allah penyelamat, sekalipun mereka masih tetap tinggal di bumi dan dihubungkan dengan situasi sesungguhnya yang akan membawa kepada akhir final bersama dengan Raja Penyelamat. ${ }^{52}$ Nubuatan dalam masa nabinabi, menunjukkan bahwa dalam sejarah Israel tidak ada masa dimana tidak ada nubuatan keselamatan di dengungkan. Hal ini juga menunjukkan bahwa nubuatan itu disesuaikan dengan situasi yang mereka alami. $^{53}$

Dalam Perjanjian Lama, para nabi Israel tidak henti-hentinya menubuatkan akan penyataan Allah kepada manusia melalui bangsa Israel tentang kedatangan Mesias. Dinubuatkan tentang: asal-usulNya (Kej. 3:15; Za. 13:1), nama (Yes. 7:2; Yes. 7:14), peristiwa Mzm. 22:2; 19), lambang (Hab. 8:26; Dan. 5:29) istilah-istilah yang disesuaikan dengan konteks sejarahan Israel (Ye. 9:6; Dan. 7:13-14; Mi. 5:1-3; Za. 9:910) dengan tujuan untuk mengingatkan bangsa Israel bahwa Allah tidak akan gagal

\footnotetext{
${ }^{53}$ Clauss Westerman, Prophetic Oracles of salvation in The Old Testament (Kentucky: John Knox Press, 1991), 34
} 
dalam menepati janji-Nya dalam melepaskan umat-Nya dari perbudakan dosa.

\section{KESIMPULAN}

Pembahasan dalam tulisan ini menyimpulkan beberapa hal. Pertama, identitas keturunan perempuan yang dimaksud dalam Kejadian 3:15 bergendre maskulin dan berjumlah satu orang. Namanya adalah Yesus Kristus, seperti yang diperkenalkan para penulis Perjanjian Baru. Kedua, Frase "keturunanmu akan meremukkan tumit keturunannya" dalam Kejadian 3 mengacu kepada penderitaan Yesus Kristus dalam misi keselamatan. Ketiga, Janji Keselamatan dalam Kejadian 3 digenapi dalam pengorbanan Yesus Kristus, sehingga dengan demikian dapat disebutkan bahwa konsep keselamatan dalam Perjanjian Baru berazaskan janji keselamatan dalam Kejadian 3:15.

\section{Daftar Pustaka}

\section{Buku}

[1]. A. Sutama, Adji. Yesus Tidak Bangkit. Jakarta: BPK Gunung Mulia

[2]. Berkof, Louis. Teologi Sistematika: Doktrin Keselamatan, Yudha Thianto, Penerjemah.

Surabaya: Momentum, 2006

[3]. Blinzler, Josef. The Trial Jesus (Westminster: The Newman Press, 1959
[4]. Bowker, John, The Targums and Rabbinic Literature. London: Cambridge University Press, 1969

[5]. Conner J, Kevin. A Practical Guide to Christian Bilief. Malang: Gandum Mas, 2004

[6]. Delitzsch and Keil. Commentary on the Old Testament: New Updated Edition, Electronic Database. Hendrickson Publishers, 1996

[7]. Dietrich Preuss, Horst. Ol Testament Theology, Volume II. Kentucky, Westminster John Knox Press, 1992

[8]. Enns, Paul. Buku Pegangan Teologi. Malang: Literatur SAAT, 2004

[9]. Evans, Tony. Who Is This King Of Glory. Batam: Gospel Press, 2005.

[10]. Foaster W, dkk.

"Keselamatan" dalam Ensiklopedi Alkitab Masa Kini. Jakarta: Yayasan Bina Kasih OMF, 2007

[11]. Geisler, Norman. Ketika Alkitab Dipertanyakan. Yogyakarta: ANDI, 2006

[12]. H. Sailhamer, John. The Expositor's Bible Comementary with the New International Version of the Holly Bible. Grand Rapids, Michigan: Zondervan Publishing House, 1991

[13]. Henry, Matthew. Commentary on the Whole Bible. PC Study Bible Formatted Electronic Database, 2006

[14]. J. W, Ethridge. The Targums of Onkelos and Jonathan Ben Ussiel on the Pentateukh. Vol. [15]. 1,2. New York: KTAV Publishing House, Inc, 1968 
Jurnal Teologi \& Pelayanan ( Kerusso )

E-ISSN: 2714-9587

P-ISSN: 2407-554X

[16]. J. Wenham, Gordon, WBC, Genesis

1-15. Thomas Nelson, 1987

[17]. Joseph Owens, John. Analytical Key Tho The Old Testament Volume 4.

Michigan: Baker Book House, 1996

[18]. Kohler, Ludwig. Old Testament Theology. Philadelphia: The Westminster Press, 1957

[19]. L Cooper, David. God and Messiah. Los Angeles: Biblical Research Society

[20]. Lasor, W.S., D.A. Hubbar, F.W. Bush. Pengantar Perjanjian Lama 1 Taurat dan Sejarah. Jakarta: BPK Gunung Mulia, 2011

[21]. M. Yates, Keyle. Tafsiran Alkitab Wyclife: Kejadian-Ester. Malang: Gandum Mas, 2004

[22]. Marantika, Chris. Doktrin

Keselamatan dan Kehidupan Rohani.

Yogyakarta: Iman Press, 2002

[23]. Mathews A, Kenneth. The New American Comentary: An Exegetical and Theological Expoxition of Holly Seripture, Peny., E. Ray Clendenen. tk: Broadman \& Holman Publisher, 1966

[24]. McDowell, Josh. Apologetika: Bukti Yang Meneguhkan Kebenaran Alkitab

[25]. McDowell, Sean. Apologetics Study Bible for Students. Nashville: B\&H

Publishing Group, 2010

[26]. Owen, John. Christians Are Forever. Surabaya: Momentum 2005

[27]. Packer, J.I. Key Bible Themes Studies of Key Bible Themes. Grand Rapids Baker, 1981
[28]. Towns, Elmer. Inti Kekristenan: Apa Sebenarnya Kekristenan Itu. Jakarta, Penerbit Nafiri Gabriel, 2011

[29]. W. E. Vince, Merrill F. Unger dan William White. Vine's Complete Expository Dictionary of Old and New Testament Words. Nashville, Atlanta: Thomas Nelson Publisher, 1996

[30]. Westerman, Claus. Elements Of Old Testament Theology. Atlanta: John Knox Press, 1978

[31]. Wiersbe, Wiersbe's Expository Old Testament (Cook Communications Ministries, 2000)

[32]. Wongso, Peter. Soteriologi, Doktrin Keselamatan. Malang: Seminari Alkitab Asia Tenggara, 1998

[33]. Wright, Christ. Tuhan Yesus memang khas dan unik. Jakarta: Yayasan Bina Kasih OMF, 2003

\section{Internet}

[34]. http://www.sarapanpagi.org/kejadian[35]. 3-15-siapa-yang-meremukkan kepalaular-vt2442.html

[36]. http://www.sarapanpagi.org/kejadian-

[37]. 3-15-siapa-yang-meremukkan kepalaular-vt2442.html

[38]. https://www.katolisitas.org/mariaadalah-perempuan-yang-disebutkan-didalam-kitab-kejadian/ 